\title{
The reform course of the oil and gas industry in US and its evaluation index system
}

\author{
Liao Jianhui ${ }^{1, a}$ \\ ${ }^{1}$ State Grid Energy Research Institute, SGCC Administrative Area, Future Science and \\ Technology Park North Area, Beiqijia Town, Changping, Beijing 102209, P.R. China;
}

ajianhuiliao@126.com

Keywords: oil and gas, reform, an evaluation of achievement.

\begin{abstract}
The reform of oil and gas industry can improve significantly the industrial efficient, sustainable and healthy development. This paper chooses United States as a representative case, reviews the whole reform course of the oil and gas industry in US, and also establish an evaluation index system which can scientifically-precisely evaluate the achievement of the oil and gas industry reform in US.
\end{abstract}

\section{The reform course of the oil industry}

So far, the oil industry in US has experienced more than one hundred years of development history. From the perspective of government imposing controls on the oil industry, The US oil industry generally experienced three stages, in turn, is free competition, government regulation, deregulation.

Before the 1930s, the overall principle of US government policy on the domestic oil industry is laissez faire, except the necessity to stern the domestic monopoly by large oil companies, the government generally does not interfere with the independent development of oil companies. However, in the aspect of international oil policy, the US government gives great support for the domestic oil companies, its purpose is to help them contest for the oversea oil resource in the international market with the multinational oil companies from Britain, France, the Netherlands and other countries.

Between the 1930s and 1970s, the U.S. government imposed regulation for oil industry. One important trigger is that the domestic oil production had increased uncontrolled before the 1930s, which triggered the oil crisis of overproduction. In 1933, President Roosevelt implemented the "New Deal", the US government abandoned the laissez-faire policy on the oil industry, started to control domestic oil production, implemented oil production quotas, and restricted the interstate oil trade and oil imports. During the period of the Nixon administration, the government began to license the increase of oil imports, phase out the import quotas, but still imposed price controls on the oil industry (Liu Ying, 2012). In 1973, the first oil crisis broke out, the US government began to realize the problem of the oil supply security, the policy priority to gradually reduce the dependence on imported oil, especially from the political instability regions, the specific policies mainly include setting up tariff barriers on imported oil, establishing the international energy agency, setting up oil 
security reserve and the mechanism of petrodollars.

The period after 1973 was deregulation phase. After the outbreak of the second oil crisis, the US government began to adjust its oil policy in the direction of deregulation. The Carter administration had canceled the restrictions on domestic oil market, and encouraged more research on the development of alternative. The Reagan administration had completely removed the price controls on oil, promoted the market-oriented reform of the oil industry, and ensure the oil security of the United States by the oil import diversified strategy. The Clinton administration had carried out petroleum diplomacy actively, on the one hand, the government continued to expand oil import channels, on the other hand, also encouraged the development and production of domestic oil. The Bush Administration had expanded strategic oil reserve capacity, and further consolidated the US-led international oil system by using military and diplomatic means. The Obama Administration has cancelled the ban on offshore oil drilling, and open the offshore oil and gas resources exploitation.

In general, the reform of the oil industry in US has experienced a long process, which was growing with the development of the oil industry. The motivation of reform came from the special development problems encountered in the period, however, the goal was clear and definite, which was to continuously improve the efficiency of the oil industry, secure the oil supply, and promote the healthy development of the industry.

\section{The reform process of the gas industry}

Before 1985, most of the pipe belonged to the gas producer with integration of upstream and downstream (Zhang qi and Zhang Weidong, 2009). From the perspective of government imposing controls on the gas industry, The US gas industry experienced three stages, in turn, is free competition, government regulation, deregulation.

In 1938, the Federal government promulgated The Natural Gas Act. Before 1938, The gas industry in US was small and in a laissez-faire competition environment. The Natural Gas Act required the government to set up Federal Power Commission (FPC), which's job was to manage the interstate natural gas pipeline transportation, set fair and reasonable prices for the gas transport service of interstate pipeline company. In this period, the regulation policy was mainly regulating the pipeline business in the middle of industry chain with the natural monopoly attribute, however, the wellhead price and the internal price in the state was regulated by the Public Utilities Commission in the state.

In the 1940s and 1950s, due to the volatility of gas price and supply shortage in some region, the United States Supreme Court unveiled the Philips Resolution in 1954, the Congress authorize the FPC to extend the price regulation to wellhead gas of state pipeline sell by the production company.

After the Philips Resolution was unveiled, there still existed two markets-interstate market and intrastate market, in the 1970s, the double-track market had caused serious problems. Because 
of the soaring of the crude oil prices, the market value of the natural gas as an alternative resources rose sharply, however, the market price of the interstate natural gas which was heavily regulated was too low, it did not reflect the market changes. A number of gas production companies escaped the interstate markets and entered to the intrastate markets, which triggered the interstate market supply shortage.

In 1978, the United States introduced The Natural Gas Policy Act, the FERC was directly responsible for the reform of the natural gas price, mainly deregulated the wellhead price of the natural gas step by step, and no longer exerted controls on the new well established after January 1, 1985. Due to the immature of the market and the information lag, in the 1980s, the natural gas industry happened the overcapacity problem, the entire industry was facing crisis.

In 1985, the FERC had issued the decree No. 436, the pipeline companies can provide open access services to a third party, the users could directly negotiate the price with the manufacturers and sign an independent delivery contracts with pipeline company, but the decree did not force the pipeline company providing public access services.

In 1989, The Natural Gas Wellhead Price Deregulation Act was unveiled, which required to cancel all of the controls on the natural gas wellhead price, and from January 1, 1993, allow the wellhead price to be decided by the market and introduce free competition.

In 1992, the FERC had issued the decree no.636, which further compulsory required that all the pipeline companies must provide public access mechanism, separate the sales and delivery service, the users should have the right to choose the gas suppliers and the pipeline companies freely. At the same time, to protect the interest of the pipeline companies, the decree stipulated that the cost recovery way of the pipeline companies was changed from the original fixed variable method into direct fixed variable method, which had played a positive role in attracting pipeline investment.

Legislation in advance is an important experience of the US's natural gas industry reform, every stage of the reform is on the premise that mandate the corresponding propulsion, its goal is to the order and legitimacy in the reform. In addition, the natural gas industry reform in US also experienced a relatively long time, however, its overall idea is relatively clear, which is just release the competitive segments in the industrial chain except the pipe distribution step by step, strengthen supervision on the natural monopoly segments, and build an independent regulatory agency and perfect supervision mechanism.

\section{An Evaluation Index System}

The goals of the reform of the oil and gas industry were multiple, to break the monopoly and improve its efficiency; at the same time, to tame the price fluctuations and ensure the energy security; in addition, also need to build the market mechanism to promote technological progress. In practice, we can set up a scientific evaluation index system to scientifically evaluate the achievement of the reform in US's oil and gas industry. 


\section{The basic principles of constructing the Index System}

(1) Comprehensiveness. The index system shall consider all the important goals of the oil and gas industrial reform, including the market structure, economic efficiency, energy efficiency, energy security, and so on.

(2) Representative. Because there are many alternative indicators under each topic layer, as to both achieve the goals of simple operation and an effective implementation, the selected indicators need to be representative, and it need to minimize the effect on the overlapping between different indicators.

(3) Operability. The selected indicators shall be operable in practice, in other words, they can be measure or judge by qualitative method or quantitative method.

\section{The construction of the evaluation index system}

While constructing the index system, the goals of the oil and gas industrial reform can be decomposed into four themes, which are respectively the market structure, economic benefits, energy efficiency and energy security, at the same time, we can choose the corresponding specific indicators under each theme layer (figure 1).

(1) Market Structure. The oil and gas industrial reform should improve competitive of the market structure of the oil and gas industry, reduce the industrial barriers to entry, open all the competitive links, strengthen the regulation of the natural monopoly link, besides, break the regional barriers among the states and establish a coordinated relationship between the federal government and the state government. Specifically, under the theme layer market structure, we can choose four representative indicators, including the degree of the domestic unified market construction, the quantity of the companies in the industry, the industrial barriers to enter, and the HHI index which can be used to measure the industrial concentration.

(2) Economic Benefits. An efficient, sustainable and healthy development of the oil and gas industry in terms of economic benefits should have such characteristics: firstly, although the market structure is tend to be more competitive, but still can guarantee that the enterprise can obtain a certain profit; secondly, reduce the price of the oil and gas products and the risk of price fluctuation; the third, the government's regulation should not produce too much regulatory costs. Accordingly, four representative indicators can be chose, they are the price level, price volatility, corporate profit and regulatory cost.

(3) Energy Efficiency. The reform should promote the efficiency of energy utilization, we can choose indicators from three aspects, the first is the leading indicator, we can choose the $R \& D$ index, which is the basis of technology promotion; the second is technology progress indicator; finally, we can the labor productivity which is a comprehensive indicator reflecting the energy efficiency.

(4) Energy Security. Energy security is also a core aim of the oil and gas industrial reform in United States, the reform should not undermine the energy security level but further strengthen it. Under energy security, we can choose three representative indicators, including the dependence of 
imports, the diversification of importation channels and energy reserves.

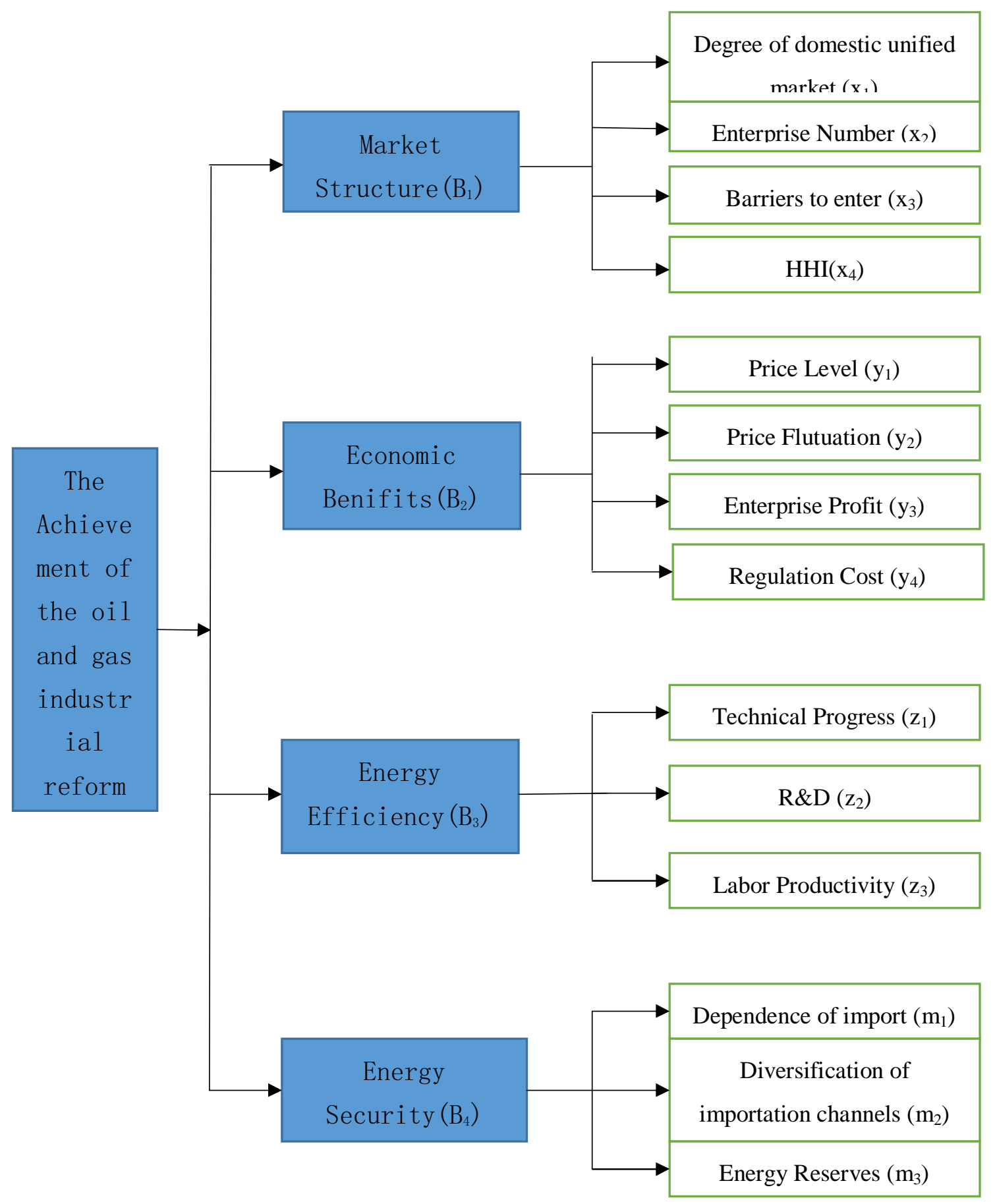

Fig.1 An achievement evaluation index system of the oil and gas industrial reform in US

\section{(3) The Calculation of the reform achievement}

Based on achievement evaluation index system of the oil and gas industrial reform in US (Figure 1), we can calculate the achievement of the reform, but before the calculation, it is need to determine the weight value of the theme layers and each index under each layer. From a practical perspective, the expert scoring method is suitable for the determination of the weights of the index 
system. The calculation method as follows:

$$
A=B_{1} \cdot \sum_{i=1}^{4} X_{i}^{\circ} \cdot x_{i}+B_{2} \cdot \sum_{i=1}^{4} Y_{i}^{\circ} y_{i}+B_{3} \cdot \sum_{i=1}^{3} \not / 0 \cdot z_{i}+B_{4} \cdot \sum_{i=1}^{3} M_{i}^{\%} \cdot m_{i}
$$

Formula (1), A is the final comprehensive value of the reform's achievement, located in the 0-100 range, the bigger shows that the oil and gas industrial reform has improved the industry, the bigger $A$, the great the achievement of the reform; $B_{1} 、 B_{2} 、 B_{3} 、 B_{4}$ are respectively the weight value of market structure, economic benefits, energy efficiency and energy security, meet the condition $B_{1}+B_{2}+B_{3}+B_{4}=10 ; x_{1} 、 x_{2} 、 x_{3} 、 x_{4}, y_{1}, y_{2}, y_{3}, y_{4}, z_{1}, z_{2}, z_{3}, m_{1}, m_{2}, m_{3}$ are respectively the value of each index, standardize them to $0-1$, the greater the value, the more optimal; the corresponding weight values of the indexes are respectively $X_{1}^{\%}, X_{2}, X_{3}, X_{4}^{\%}, Y_{1}^{/ /}, Y_{2}^{/ /}, Y_{3}, Y_{4} / \mathrm{c}$,

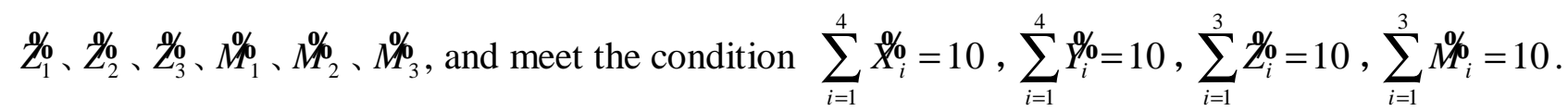

\section{The Conclusion}

The reform of the oil and gas industry is the important driving force to promote the development of the oil and gas industry, from a global perspective, the reform of the oil and gas industry in United States has certain representativeness. Therefore, this article firstly reviews the reform history and the experience of the oil and gas industrial reform in United States. Further, as to evaluate the achievement of the reform, this article establish the achievement evaluation index system of the oil and gas industrial reform in US, which can provide a scientific evaluation framework for the oil and gas industrial reform in the United States.

\section{Reference:}

[1] Liu Ying. The United States government's regulation on the oil price in the 1970s. Inquiry into Economic Issues, 2012(4):179-182.

[2] Zhang qi, Zhang Weidong. The experience and enlightenment of the development of the natural gas industry in the United States. International Petroleum Economics, 2009(6):22-25. 